\title{
Simulation of Wastewater Depolution Processes by Advanced Biological Methods
}

\author{
OANA STELA MIREL ${ }^{1 *}$, CONSTANTIN FLORESCU ${ }^{2 *}$ \\ ${ }^{1}$ University of Ottawa, 75 Laurier Ave E, Ottawa, ON K1N 6N5 \\ ${ }^{2}$ Politehnica University Timisoara, Civil Engineering Faculty, Department of Hydrotechnical Engineering, 1A George \\ Enescu Str., 300022, Timisoara, Romania
}

\begin{abstract}
This paper presents the results from a study which simulates wastewater depollution processes using advanced biological methods. The experimental research was performed in a static biological reactor, equipped with an air compressor and an agitator / mixer. Synthetic wastewater, prepared with the addition of glucose, was fed into the reactor. The wastewater was subjected to alternating cycles of aeration and slow mixing, for consecutive $3 \mathrm{~h}$ intervals within the reactor to ensure the necessary conditions for the reduction of nitrogen based organic compounds within the wastewater. In the successive aeration processes, aerobic / nitrifying microorganisms which developed within the reactor, facilitated the decomposition of organic substances into nitrites and then into nitrates. By stopping aeration and starting the slow mixing cycle the anaerobic / denitrifying microorganisms growing in the reactor consume the necessary oxygen from nitrates and release free nitrogen into the atmosphere, thus completing the process of advanced depollution. Therefore, the experimental procedure highlights the existence of two distinct phases in the development of the depollution process. In the first phase, the biological process is initiated using glucose in order to promote the growth of the bacterial flora. In the second phase (the regime phase), the reduction of mineral and organic pollutants from the wastewater is ensured. The activity of microorganisms in the biological reactor can be further supported by the recirculation of activated sludge retained in the secondary decanter. The proposed technology offers a fast, safe and relatively inexpensive method for advanced wastewater depollution. Bioreactors of this type are recommended in wastewater treatment schemes in the hearth of rural localities, agrozootechnical complexes and tourist units with seasonal activities due to their fluctuations in hourly wastewater flow rates. Similar approaches can also be considered for the elimination of ammonium compounds in groundwater polluted with animal manure.
\end{abstract}

Keywords: biological reactor, nitrification-denitrification ammonium, nitrites, nitrates

\section{Introduction}

Wastewater from the hearth of populated centres or from different types of human activities is a significant source of environmental pollution. The elimination or reduction of pollutants from sewage water is ensured using specific treatment technologies. The selection of treatment technologies is governed by the origin of the wastewater, its physical, chemical and biological characteristics as well as the flow size, reactor type, feed mode (continuous or intermittent) and operational costs [1-5].

The technological scheme of an advanced wastewater treatment plant, shown in Figure 1, is presented as a sequence of installations arranged to form a water treatment line and a sludge treatment line. The water line consists of the following technological objects: 1-grills, de-sanders and grease separators, for retaining the coarse suspensions from the influent; 2-primary decanters, for retaining fine suspensions; 3-biological reactors which implement an advanced treatment process (nitrification-denitrification); 4secondary decanters used to finalize the clarification process before the effluent is discharged into the natural emissary.

*email: omire056@uottawa.ca, constantin.florescu@upt.ro 
The sludge line consists of the following technological objects: 5-tanks for recirculating, collecting and thickening excess sludge from primary and secondary decanters; 6-anaerobic fermentation tanks for biogas or biohydrogen production; 7-gasometers for collecting gases produced from fermentation; 8thermal power plant; 9- a tank to facilitate the dehydration of fermented sludge; 10-storage platform for fermented sludge. The meaning of the other notations follows: WW-wastewater; CW-treated water (clear water); MR- recirculated activated sludge (recirculated mud); EM- excess activated sludge (excess mud); FF-recovery of activated sludge for agricultural purposes (i.e. fertilizer) [1, 2, 5-12].

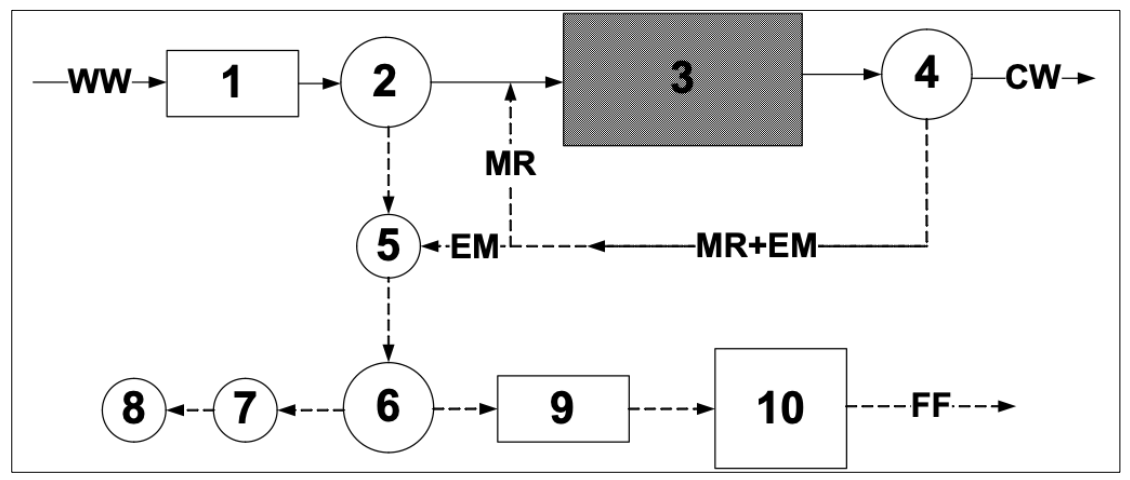

Figure 1. Technological scheme of advanced wastewater treatment

The biological reactor, depicted in Figure 1, is the technological object in which the nitrification / denitrification processes take place and thus is responsible for facilitating the reduction / elimination of organic carbon, nitrogen and phosphorus-based pollutants contained in wastewater. Biological nitrification / denitrification processes can take place in: common / separate basins; static / dynamic basins (with continuous or intermittent supply); closed / open basins; common basins with distinct aeration / mixing areas; common reactors composed of a sequence of installations in which the 5 operations (filling, aeration, sedimentation, clarified water evacuation and excess sludge evacuation) are repeated at $24 \mathrm{~h}$ intervals; static reactors with successive aeration / mixing cycles every $3-4 \mathrm{~h}$ which is an alternative promoted in this study $[1,9,12,15-21]$.

Nitrification is the process by which the oxidation of ammonium compounds in wastewater occurs. This process takes place in two stages: in the first stage, oxidation leads to the formation of nitrites, and in the second to the formation of nitrates. Two types of chemoautotrophic bacteria are present within these reactions and obtain their necessary energy by oxidizing organic compounds from the wastewater $[1,8,9,16]$.

In the first phase, the ammonium compounds are oxidized by aerobic autotrophic bacteria (nitrosomonas) to form nitrite, according to the reaction:

$$
2 \mathrm{NH}_{4}{ }^{+}+3 \mathrm{O}_{2} \rightarrow 2 \mathrm{NO}_{2}{ }^{-}+2 \mathrm{H}_{2} \mathrm{O}+4 \mathrm{H}^{+}
$$

In the second phase, nitrite oxidation takes place by nitrobacteria to form nitrate, according to the reaction

$$
2 \mathrm{NO}_{2}^{-}+\mathrm{O}_{2} \rightarrow 2 \mathrm{NO}_{3}^{-}
$$

The final result of the two oxidation phases is given by the reaction:

$$
\mathrm{NH}_{4}{ }^{+}+2 \mathrm{O}_{2} \rightarrow \mathrm{NO}_{3}{ }^{-}+\mathrm{H}_{2} \mathrm{O}+2 \mathrm{H}^{+}
$$

Denitrification is the biological process of reducing nitrates into nitrogen gas, using heterotrophic bacteria, which require organic carbon as an energy source [20,21]. 
Heterotrophic $\left(\mathrm{C}_{\text {org }}\right)$ and autotrophic $\left(\mathrm{CO}_{2}\right)$ bacteria work together to produce ammonium from existing nitrogen $\left(\mathrm{N}_{\text {org }}\right)$ in decomposed organic compounds. These types of bacteria need an aerated environment to survive.

In the second phase, the denitrifying bacteria are deprived of free oxygen from water and thus, are forced to consume the oxygen bound to nitrates which facilitates the decomposition of pollutants from water into simple compounds. The reaction of the denitrification process is of the form:

$$
5 \mathrm{C}_{\text {organic }}+4 \mathrm{H}^{+}+4 \mathrm{NO}_{3}^{-} \rightarrow 5 \mathrm{CO}_{2}+2 \mathrm{~N}_{2}+2 \mathrm{H}_{2} \mathrm{O}
$$

Carbon sources can consist of: glucose $\left(\mathrm{C} \mathrm{H}_{12} \mathrm{O}_{6}\right)$, methanol $\left(\mathrm{CH}_{3} \mathrm{OH}\right)$, molasses, ethanol and organic substances, easily absorbed by denitrifying bacteria [1, 16, 24].

Denitrification reactions for glucose and methanol, as carbon sources, are given by the following equations:

$$
\begin{gathered}
24 \mathrm{NO}_{3}{ }^{-}+5 \mathrm{C}_{6} \mathrm{H}_{12} \mathrm{O}_{6} \rightarrow 30 \mathrm{CO}_{2}+18 \mathrm{H}_{2} \mathrm{O}+24 \mathrm{OH}+12 \mathrm{~N}_{2} \\
6 \mathrm{NO}_{3}{ }^{-}+5 \mathrm{CH}_{3} \mathrm{OH} \rightarrow 5 \mathrm{CO}_{2}+7 \mathrm{H}_{2} \mathrm{O}+6 \mathrm{OH}+3 \mathrm{~N}_{2}
\end{gathered}
$$

Nitrogen gas, produced in the nitrification-denitrification processes, is released into the atmosphere and is integrated into the Earth's nitrogen cycle [22].

Nitrites and nitrates in water are the products of natural processes. The Earth's atmosphere contains about $78 \%$ nitrogen gas $\left(\mathrm{N}_{2}\right)$, which is then converted to ammonia $\left(\mathrm{NH}_{3}\right)$ by nitrogen-fixing bacteria in the soil or in the roots of certain plants. Ammonia is then used in nitrification processes to produce nitrites $\left(\mathrm{NO}_{2}^{-}\right)$and nitrates $\left(\mathrm{NO}_{3}^{-}\right)$. Ammonia Oxidizing Bacteria (AOB) oxidize ammonia to produce nitrites, which is then further oxidized by Nitrogen Oxidation Nitrobacteria (NOB) to produce nitrates. Nitrates can be harmful to the environment because they often come from chemical fertilizers that leak or are discharged into streams, seas and oceans and other bodies of water. Although these products give rise to the inflorescence of algae in bodies of water, which is important to the survival and presence of aquatic life, they can also cause methemoglobinemia and other disorders in humans, when consumed in large quantities $[1,15,19,23]$.

Current treatment solutions available for the removal of nitrites and nitrates from wastewater mainly employ the effects of aerobic and anaerobic bacteria. The microbiological processes associated with nitrification and denitrification can be facillitated using two separate bioreactors or a single bioreactor divided into two areas so that each reaction is facilitated separately. In both setups, the untreated water can undergo treatment under a stationary or dynamic regime, with continuous or intermittent flow.

The outlined experiment combines the nitrification-denitrification process within a single static bioreactor and thus, presents a more efficient and significantly faster solution for wastewater depollution. Furthermore, the proposed solution requires low investment and operational costs since it eliminates the need for an external carbon source and reduces the amount of oxygen required to stimulate the aerobic bacterial growth which facilitates the consumption and removal of organic matter in the water. Through this technological system, the efficiency of removing total nitrogen from wastewater can reach values of up to $60-80 \%$.

\section{Experimental part}

The bioreactor used to simulate the processes of advanced wastewater depollution, shown in Figure 2 , is a rectangular plastic container $(90 \times 30 \times 30 \mathrm{~cm})$, equipped with a fine bubble aeration system fixed on the bottom of the container and connected to an air compressor. The bioreactor also contains an agitator/mixer with reduced rotational movement $(\mathrm{n}=10$ rot./min.) in order to homogenizes the air from the atmosphere and the air from the aeration system within the water. 
The experiments were performed with natural water, taken from a nearby pond. $10 \mathrm{~L}$ of the water sample was mixed with $100 \mathrm{~g}$ of glucose, in order to provide the nutrients necessary for the development of the bacterial flora necessary to sustain the nitrification / denitrification processes. The temperature of the water in the biological reactor was $20-22^{\circ} \mathrm{C}$. The water samples were collected in containers with a capacity of $100 \mathrm{~mL}$, after every $6 \mathrm{~h}$ of aeration / mixing [24].

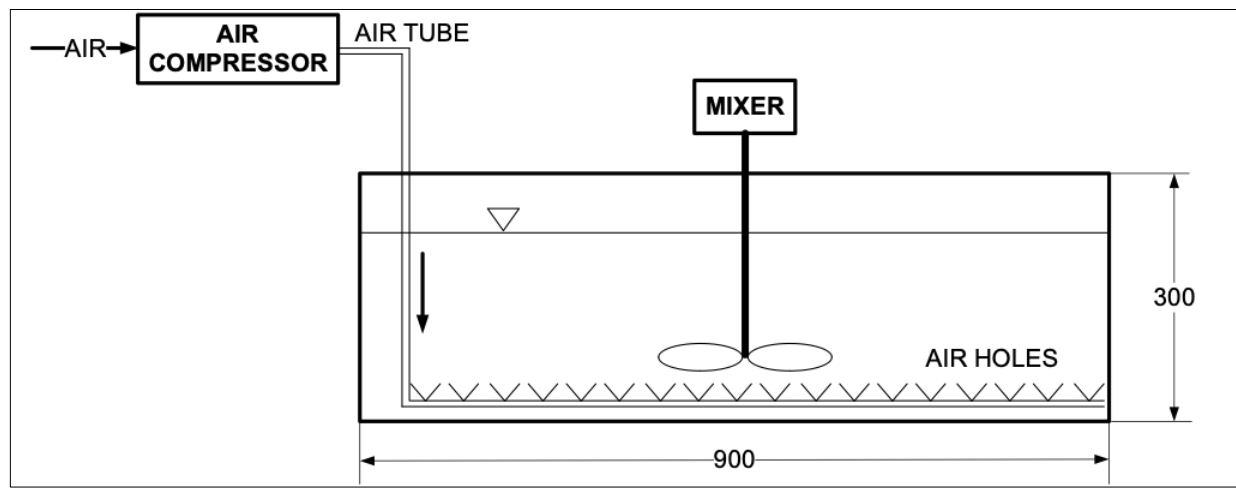

Figure 2. Scheme of the experimental bioreactor

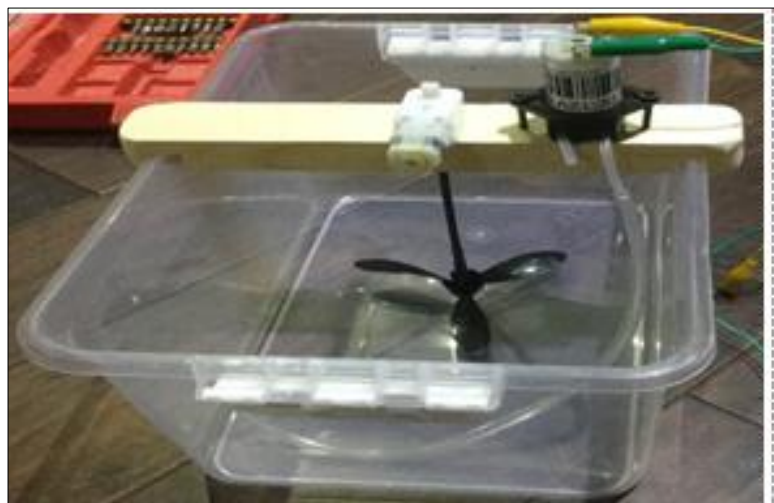

Figure 3. Bioreactor with the mixer at rest

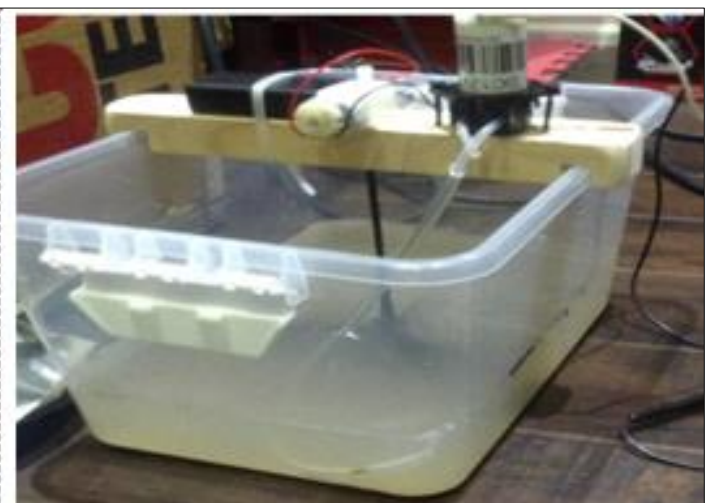

Figure 4. Bioreactor with mixer in operation

Figure 3 shows the installation of the bioreactor with its mixer at rest. In Figure 4, the bioreactor is depicted while the mixer is in operation.

The purpose of the experiment was to highlight the change in water quality indicators during the nitrification - denitrification process carried out in the static biological reactor.

The independent variables over the treatment process include: the number and duration of the aeration-mixing cycles, and the dependent ones, by the quality parameters of the treated water.

The quality of the treated water in the biological reactor was monitored based on the change in concentration of the following indicators over a given period of time: biochemical oxygen content (BOD5), dissolved oxygen $\left(\mathrm{O}_{2}\right)$, concentrations of nitrites $\left(\mathrm{NO}_{2}{ }^{-}\right)$, nitrates $\left(\mathrm{NO}_{3}{ }^{-}\right)$, total nitrogen Kjeldahl (TKN) and $p \mathrm{H}$. The obtained experimental values were analyzed in relation to the limits of each indicator defined by the norms and established national parameters [3, 19, 21, 23, 24].

The analysis of the water samples was performed in the laboratories of The Ashbridges Bay Wastewater Treatment Plant in Toronto, Canada. The control variables include: volume of water analyzed, volume and shape of the bioreactor (rectangular or cylindrical), number of slow mixers, aeration and mixing times, amount of glucose added, number of aeration / mixing cycles, amount of oxygen blown and bioreactor water temperature.

The qualitative characteristics of the water in the biological reactor are given in Table 1. 
Table 1

\begin{tabular}{|c|c|c|c|c|c|c|c|c|}
\hline $\begin{array}{c}\text { Number } \\
\text { Cycle }\end{array}$ & $\begin{array}{l}\text { Duration } \\
(\mathrm{H})\end{array}$ & $\begin{array}{c}\mathrm{O}_{2} \\
(\mathrm{mg} / \mathrm{l})\end{array}$ & $\mathrm{pH}$ & $\begin{array}{l}\mathrm{NO}_{2-} \\
(\mathrm{mg} / \mathrm{l})\end{array}$ & $\begin{array}{l}\mathrm{NO}_{3-}- \\
(\mathrm{mg} / \mathrm{l})\end{array}$ & $\begin{array}{c}\mathrm{TKN} \\
(\mathrm{mg} / \mathrm{l})\end{array}$ & $\begin{array}{l}\mathrm{BOD}_{5} \\
(\mathrm{mg} / \mathrm{l})\end{array}$ & Process \\
\hline 0 & 0 & 1.06 & 6.7 & 0.005 & $<0.02$ & 0.25 & 34.56 & Raw water \\
\hline \multirow{2}{*}{1} & 3 & 1.12 & 6.0 & 0.005 & $<0.02$ & $<0.2$ & 76.02 & Aeration \\
\hline & 3 & \multicolumn{7}{|c|}{ Mixing } \\
\hline \multirow{2}{*}{2} & 3 & 1.04 & 6.0 & 0.004 & $<0.02$ & $<0.2$ & 75.74 & Aeration \\
\hline & 3 & \multicolumn{7}{|c|}{ Mixing } \\
\hline \multirow{2}{*}{3} & 3 & 0.98 & 5.5 & 0.005 & $<0.02$ & $<0.2$ & $>86.24$ & Aeration \\
\hline & 3 & \multicolumn{7}{|c|}{ Mixing } \\
\hline \multirow{2}{*}{4} & 3 & 1.27 & 6.1 & $<0.004$ & $<0.02$ & $<0.2$ & 70.28 & Aeration \\
\hline & 3 & \multicolumn{7}{|c|}{ Mixing } \\
\hline
\end{tabular}

\section{Results and discussions}

Biochemical oxygen consumption at day 5 (BOD5) provides the concentration of biodegradable organic substances present in the wastewater and thus, is a measure of pollution levels in the water sample. This parameter is a measure of the amount of dissolved oxygen $\left(\mathrm{O}_{2}\right)$ present in a water sample, available to aerobic organisms for the decomposition of organic matter. The higher the $\mathrm{BOD}_{5}$ concentration, the lower the dissolved oxygen concentration in the water. The concentration of dissolved oxygen in water depends on the temperature of the water, the pressure of the atmospheric air, the content of oxidizable substances as well as the type and density of microorganisms.

The decrease below the allowed limit of the amount of dissolved oxygen in natural water courses, substantially reduces the self-purification capacity of the emissions, favouring the development of the eutrophication processes and increases water pollution [1, 5, 23].

The nitrification-denitrification processes in the experimental bioreactor could be measurably evaluated only after the completion of the priming period, during which bacterial flora developed. The presence of the bacterial flora achieves the reduction of ammonium-based compounds in wastewater, defining the priming period as a decisive stage in the development of the regime period.

Figure 5 shows the change in $\mathrm{BOD}_{5}$ concentration over time within the experimental bioreactor during four alternative aeration / mixing cycles.

The reference results were interpolated over a period of $24 \mathrm{~h}$, resulting in a parabolic shape function. Experimental measurements for $\mathrm{BOD}_{5}$ exhibited slow growth trend in the first $18 \mathrm{~h}$ and then decreased until the end of the $24 \mathrm{~h}$ cycle.

The initial water sample taken had a low organic load and therefore, it was necessary to administer a quantity of $100 \mathrm{~g}$ of glucose in $10 \mathrm{~L}$ of the treated water. The glucose provided the organic substrate necessary for the development of bacterial flora responsible for carrying out the nitrification denitrification processes in the biological reactor. 


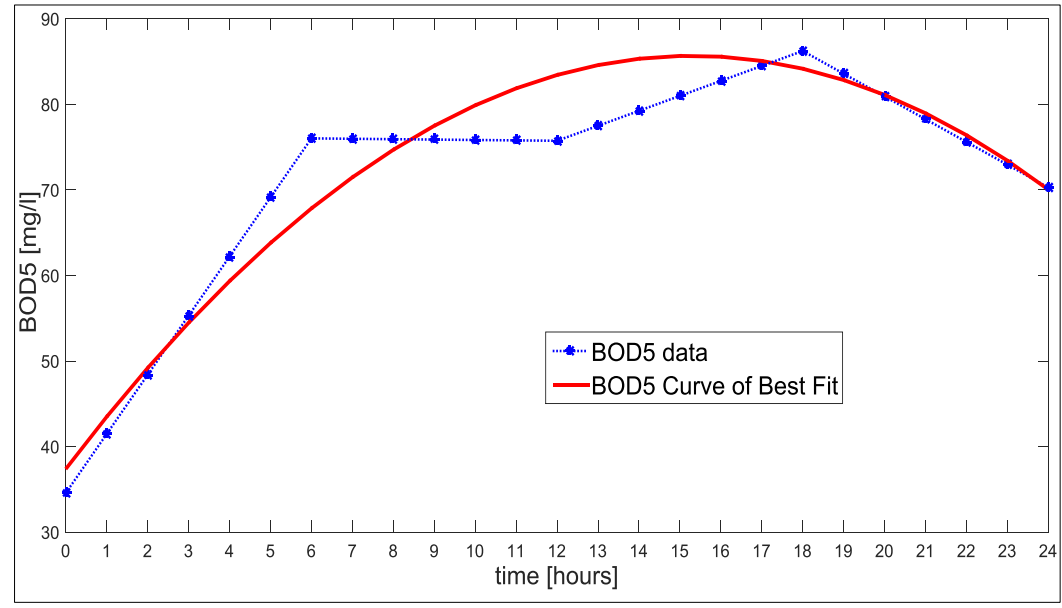

Figure 5. Evolution over time of $\mathrm{BOD}_{5}$ concentration in the biological reaction

The water samples analyzed in the Toronto Wastewater Treatment Plant Laboratory showed an increase in the $\mathrm{BOD}_{5}$ concentration of the treated water from $34.56 \mathrm{mg} / \mathrm{L}$ to a maximum of $86.24 \mathrm{mg} /$ $\mathrm{L}$, followed by a decrease to $70.28 \mathrm{mg} / \mathrm{L}$, after approximately 4 cycles of aeration and mixing. This decrease continued until the $\mathrm{BOD}_{5}$ concentration dropped below the admissible limit of $20 \mathrm{mg} / \mathrm{L}[1,3$, 26].

The experimentally derived $\mathrm{BOD}_{5}$ values had a slow increase during the first $18 \mathrm{~h}$, followed by a decrease in the remaining $6 \mathrm{~h}$ of the experiment. The low concentration of microorganisms present in the pond water before treatment contributed to the experiments delayed entry into the regime period, by about 12 to $18 \mathrm{~h}$.

In relative terms, the experimental $\mathrm{BOD}_{5}$ concentration in the bioreactor begins to decrease only after the priming period. These findings are tied to the reduced bacterial concentrations in our initial water sample. $\mathrm{BOD}_{5}$ concentrations in the bioreactor can be reduced by increasing the duration of aeration and mixing cycles and by adding additional activated sludge from secondary decanters.

A priming stage or an an incubation period, is essential for the growth and development of microorganisms and is facilitated by adding of glucose and oxygen (using an aeration system) to the initial polluted water sample. This priming stage should last at least a couple of days in order to allow for significant amounts of bacteria to develop and later facilitate the nitrification-denitrification processes required to reduce or eliminate ammonium from the polluted water. When in operation, the priming period of the bioreactor, can be reduced by the contribution of activated sludge from an operating treatment plant.

In the second stage, designated as the regime period, the nitrification-denitrification processes are carried out in order to reduce / eliminate ammonium-based organic compounds from the wastewater.

The experimental results obtained via the static bioreactor were compared with quality parameters obtained from the treatment plant of a city (B) with approximately 150,000 inhabitants. The biological treatment stage of this plant is facilitated using two distinct basins: one for the development of nitrification and the other for the denitrification processes. The wastewater from the locality is collected through a network of canals with a total length of over $150 \mathrm{~km}[11,19]$.

Figure 6 shows the change in biochemical oxygen consumption $\left(\mathrm{BOD}_{5}\right)$ of the treatment plant of city $\mathrm{B}$ over $24 \mathrm{~h}$ following a 5 day period in the biological stage. In the first hours, the graph shows a slight upward trend in $\mathrm{BOD}_{5}$ levels which is necessary to start the treatment process. The slow decrease in the $\mathrm{BOD}_{5}$ levels marks the start of the regime period. This trend continues until the end of the $24 \mathrm{~h}$ interval where the values obtained are below the permitted limits. The wastewater reaches the treatment plant after about 2-3 days, during which time some of the useful microorganisms needed to start the treatment process could develop. The concentration of Biochemical Oxygen Consumption (BOD5) in the water 
entering the treatment plant was $85 \mathrm{mg} / \mathrm{L}$ which is high enough for the development of advanced nitrification - denitrification processes.

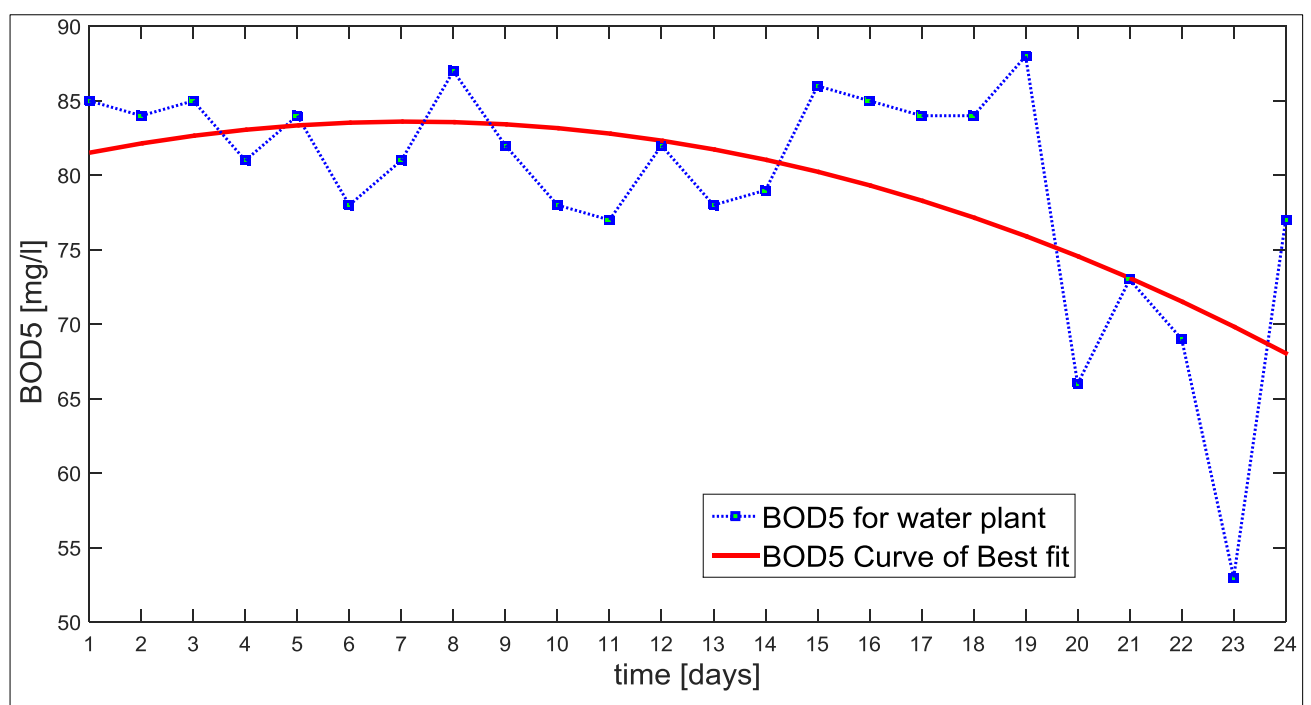

Figure 6. The change in $\mathrm{BOD}_{5}$ concentrations over time after undergoing the biological stage at the sewage treatment plant of city B

The changes in the concentrations of Nitrites, Nitrates and TKN over time for the water samples collected from the biological reactor, during a $24 \mathrm{~h}$ cycle, are shown in Figure 7.

According to Ontario Water Standards, the total concentration of nitrates and nitrites may not exceed $0.1 \mathrm{mg} / \mathrm{L}$ when both compounds are present in water. The raw water from the natural pond had a nitrite concentration of $0.005 \mathrm{mg} / \mathrm{L}$ while for the treated water, values ranged between $0.005 \mathrm{mg} / \mathrm{L}$ and 0.004 $\mathrm{mg} / \mathrm{L}$. Since these values are so small, these fluctuations are considered as measurement errors. The nitrate concentration in the treated water also remained constant $(0.02 \mathrm{mg} / \mathrm{L})$ and unchanged from the water in the natural pond used.

When analyzing the total nitrogen parameter or TKN (Nitrogen Total Kjeldhal), the untreated water samples showed a concentration of $0.25 \mathrm{mg} / \mathrm{L}$ which is well above the permitted limit of $0.1 \mathrm{mg} / \mathrm{L}$. After the first aeration-mixing cycle of six hours, the TKN concentration decreased to a concentration less than $0.1 \mathrm{mg} / \mathrm{L}$. Total nitrogen can be determined by the equation:

$$
\text { Total- } \mathrm{N}=\mathrm{TKN}+\mathrm{NO}_{3}{ }^{-}+\mathrm{NO}_{2}^{-}
$$

Based on this relationship, the water samples showed a reduction of total nitrogen by 22-23\% compared to the raw sample. The percentage of total nitrogen reduction can be obtained by increasing the frequency and duration of the aeration / mixing cycles. 


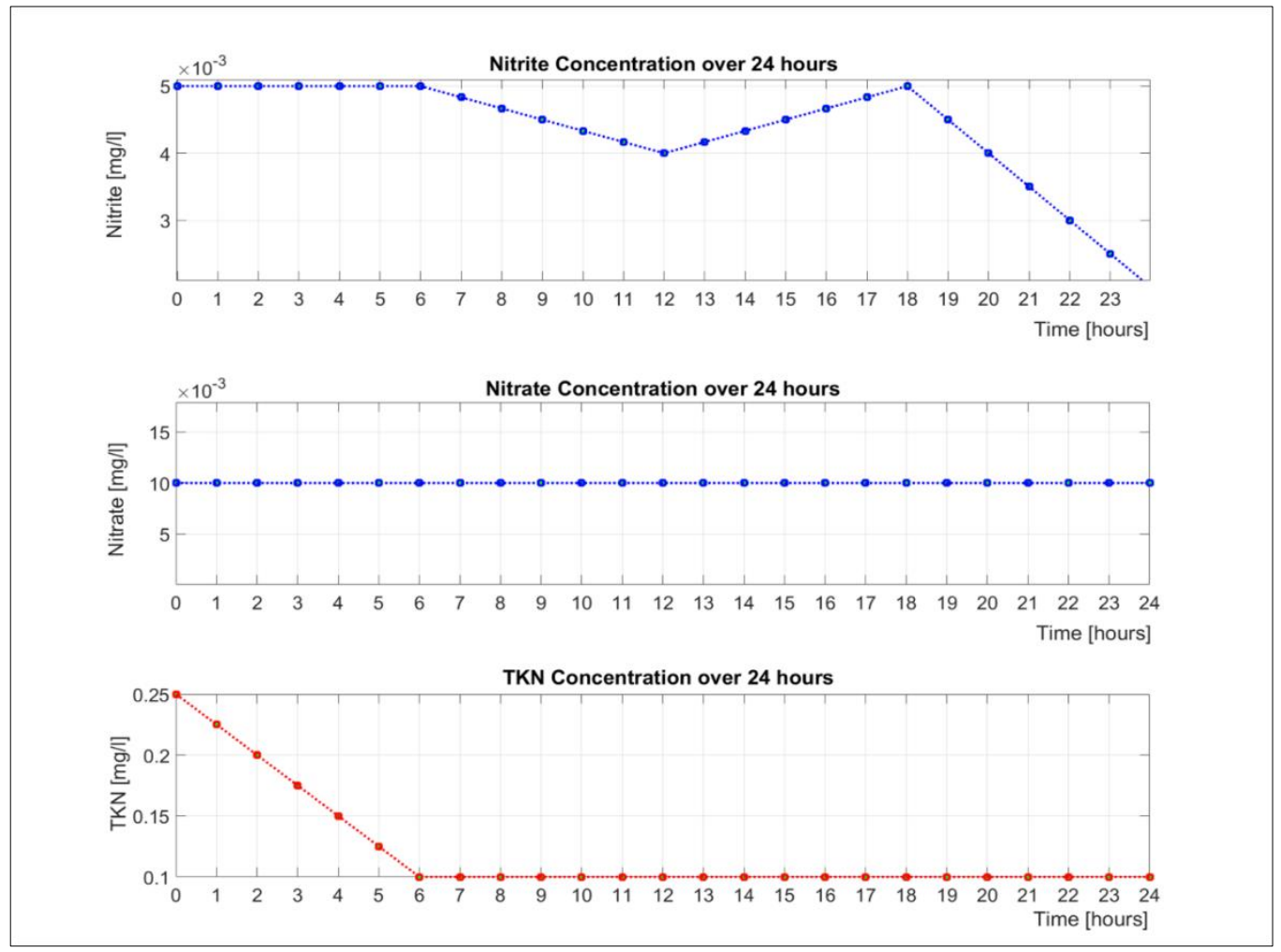

Figure 7. Evolution of Nitrite, Nitrate and TKN concentrations

Dissolved Oxygen $\left(\mathrm{O}_{2}\right)$ concentration is perhaps the most important parameter to monitor with regard to the prosperity and survival of an aquatic exocystem. This parameter is dependent on the duration of aeration. The changing levels of this parameter over time are illustrated in the linear expression shown in Figure 8.

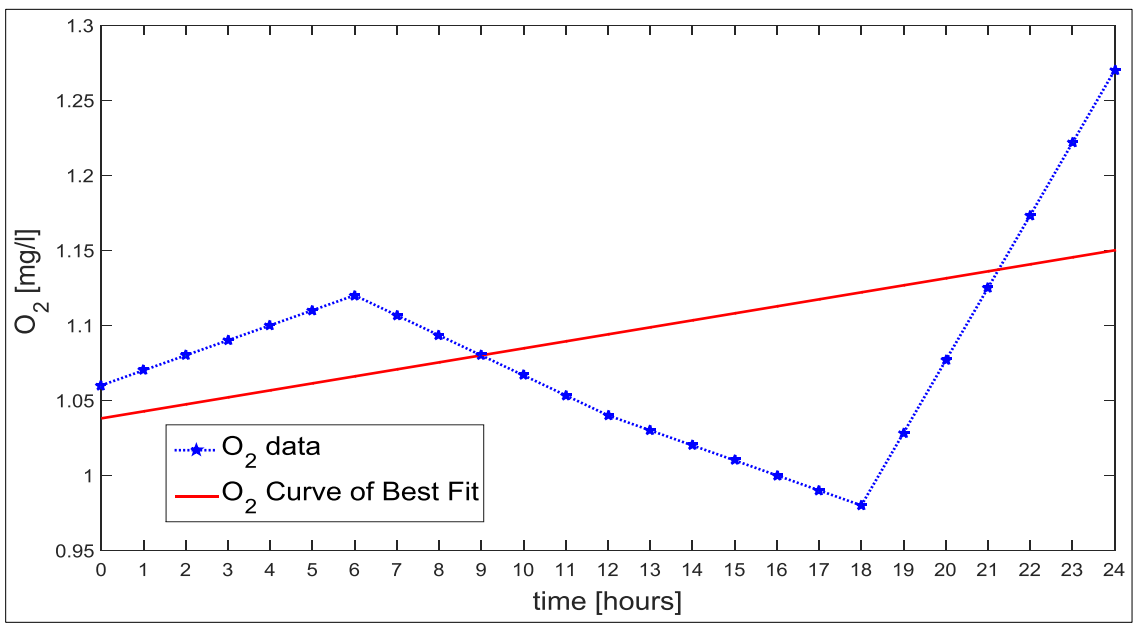

Figure 8. The change in dissolved oxygen $\left(\mathrm{O}_{2}\right)$ concentration over time

The water in the biological reactor had an initial $\mathrm{O}_{2}$ concentration of $1.06 \mathrm{mg} / \mathrm{L}$, which after the first aeration cycle increased to $1.12 \mathrm{mg} / \mathrm{L}$. At the end of the last aeration cycle the $\mathrm{O}_{2}$ concentration reached $1.27 \mathrm{mg} / \mathrm{L}$. This concentration is not sufficient to sustain life in an aquatic environment. Crabs, oysters and worms survive on low concentrations of dissolved oxygen $\left(\mathrm{O}_{2}\right), 16 \mathrm{mg} / \mathrm{L} \mathrm{O}$, while fish living in bodies of shallow water need very high concentrations of dissolved oxygen, about $415 \mathrm{mg} / \mathrm{L} \mathrm{O}_{2}$. 
The decomposition of organic matter in wastewater is carried out by oxygen-consuming bacteria. This relationship is highlighted given the correlation between $\mathrm{BOD}_{5}$ and $\mathrm{O}_{2}$ concentrations: an increased deficiency in dissolved $\mathrm{O}_{2}$ occurs when reducing biochemical oxygen consumption to 5 days (BOD 5 ).

The experimental results show that the lowest concentration of $\mathrm{BOD}_{5}(70.28 \mathrm{mg} / \mathrm{L})$ corresponded to the highest concentration of $\mathrm{O}_{2}(1.27 \mathrm{mg} / \mathrm{L})$, while the highest concentration of $\mathrm{BOD}_{5}$ corresponded to the lowest concentrations for $\mathrm{O}_{2}(0.98 \mathrm{mg} / \mathrm{L})$. The high concentration of oxygen in the bioreactor was determined by the fact that the aerobic bacteria in the water did not start to grow.

The $p \mathrm{H}$ of water is a measure of the relative amount of free hydrogen and hydroxyl ions. In bodies of water $p \mathrm{H}$ is mitigated via the carbon dioxide-bicarbonate-carbonate equilibrium.

Therefore, a higher concentration of carbon dioxide will reduce the $p \mathrm{H}$, while a lower concentration will increase it. The variations in $p \mathrm{H}$ in bioreactor over time are given by the parabolic function shown in Figure 9.

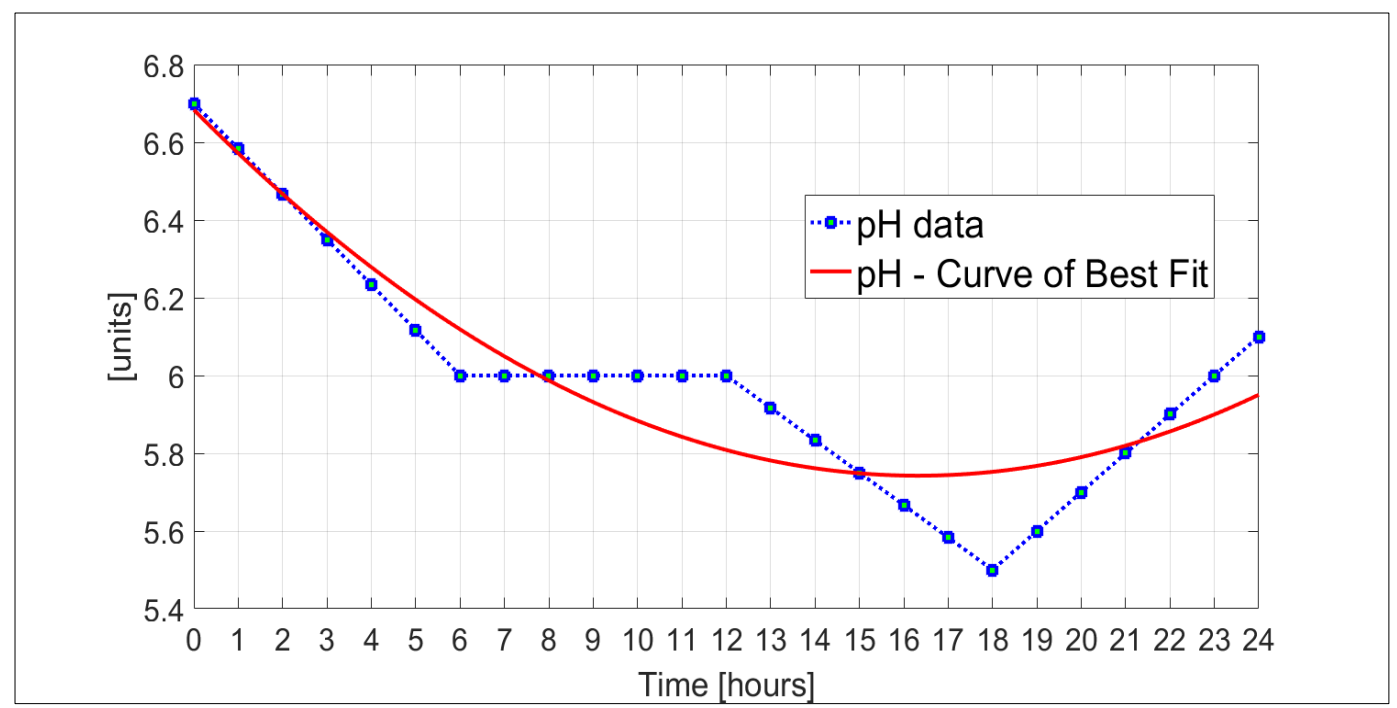

Figure 9. The change in $p \mathrm{H}$ over time

The untreated water taken from the pond had a $p \mathrm{H}=6.7$ which is within the permitted limits of the parameter $(p \mathrm{H}=6.5-8.5)$. After the first aeration / mixing cycle, the $p \mathrm{H}$ dropped to 6.0 and then to 5.5 after the third aeration cycle $(18 \mathrm{~h})$. At the end of the fourth aeration cycle $(24 \mathrm{~h})$ the $p \mathrm{H}$ value increased to 6.1. Since glucose is a molecular solid, it could not be responsible for the change in $p \mathrm{H}$ of the bioreactor water. Therefore, the decrease in the water $p \mathrm{H}$ can be attributed to the stimulation of bacterial activity during the denitrification process. The denitrifying bacteria developed during denitrification consumed the glucose (carbon source) and produced more hydroxide ions, which affected the $p \mathrm{H}$.

\section{Conclusions}

In this paper, wastewater depollution processes are simulated using a static bioreactor that implements advanced biological nitrification-denitrification processes. The experimental research performed using synthetically prepared wastewater, to which glucose was added, highlights the existence of two distinct phases within the bioreactor. The first phase is the priming process required for the development / growth of bacterial flora. The second phase, also called the regime phase, is defined by the advanced purification processes.

The processes of nitrification and denitrification are simulated using alternating biological processes of aeration and agitation with the goal of reducing organic substances in treated water to form free nitrogen. The process of nitrification/oxidization was carried out in the biological reactor through the use of a fine bubble aeration system for $3 \mathrm{~h}$ intervals. Next, in the denitrification stage, in which nitrates were reduced, aeration was stopped and the water in the reactor was agitated using of slow-mixers for a 
$3 \mathrm{~h}$ period. During the denitification reaction, anerobic microorganisms consumed oxygen bound to nitrates causing the release of free nitrogen. The proposed technology offers a fast, safe and relatively inexpensive method for wastewater treatment. The bioreactor model presented is recommended for wastewater treatment schemes in rural homes, localities and touristic complexes with seasonal activity, where the effluent has large hourly oscillations in flow. Furthermore, static bioreactors, that employ advanced water depollution treatments using nitirifcation and denitifrication processes, can be used to treat water polluted with animal waste products. This method can prove potentially usefully in neutralizing animal manure discharged from farms and agricultural complexes and transforming into crop fertilizer.

\section{References}

1. DIMA, M., MEGLEI, V., DIMA, B., BADEA C., Bazele epurarii biologice a apelor uzate. ETP Tehnpress Iasi, 2002, p.162-206.

2. KAINZ, H., KAUCH, E.P., RENNER, H., Siedlungswasserbau und Abfallwirtschaft. Manz Verlag Schulbruch, Wien, 2002, p.227-249.

3. *** Environment and Climate Change Canada. Wastewater Treatment Practice and Regulations in Canada and Other Jurisdictions. Canadian Water Network, 2018.

4. *** Ontario Ministry of the Environment. Technical Support Document for Ontario Drinking Water Standards, Objectives and Guidelines. Ontario Legislative Library, 2003 rev. 2006.

5. *** Water Treatment Handbook. Ed. Degremont, Water and Enviroment, 1991, Vol.1, 2. p. 72-84, 283-362.

6. BOBOESCU, I. Z., GHERMAN, V. D., MIREL, I., MAROTI, G., NEGREA, A., CIOPEC, M., MOTOC, M., Development of a Two-step Fermentative Biohydrogen Production Process Using Selectively Enriched Microbial Populations as Inoculum. Rev. Chim., 64(8), 2013, 919-924

7. BOBOESCU, I. Z., ILIE M., GHERMAN, V. D., MIREL, I., PAPP, B., NEGREA, A., KONDOROSI E., BIRO, T., MAROTI, G., Revealing the factors influencing a fermentative biohydrogen production process using industrial wastewater as fermentation substrate. Biotechnology for Biofuels, 2014, 7: 139. 8. JACOB, R., \& CORDARO, E., Nitrification. RPI, Fall 2000.

9. MARTINEZ, S.G., Alternating aerobic and anaerobic operation on an activated sludge plant. JWPCF, februarie, 1987.

10. MIREL, I., ISACU M., BAKOS M., Harnessing the untapped renewable energy potential of the organic Loads of urban wastewater. International Multidisciplinary $12^{\text {th }}$ Scientific Geoconference SGEM 2012, vol. IV, 17-23 june. 2012, Bulgaria, p. 515-523.

11. NICOLAU, M., PETROESCU, V., COSMA, C., DINU, L., BUMBAC, C., Intensive Biological Proces Based on SBR Reactor for Industrial Waste water Treatment, Rev. Chim., 59(10), 2008, 11061111

12. ROBESCU, D., LANYI, S., ROBESCU, D., CONSTANTINESCU, I., VERESTOY, A., Wastewater Treatment Tehnologies, Installations and Equipment. Editura Tehnica Bucuresti, 2001, p. 269-279.

13. STANILOIU, C., FLORESCU, C., Consideration for Optimisation of Biological Treatment Process for Small Wastewater Treatment Plant, Rev. Chim., 65(4), 2014, 502-505

14. ROBESCU, D., LANYI, S., VERESTOY, A, ROBESCU, D., Modelarea si simularea proceselor de epurare. Editura Tehnica Bucuresti, 2004, p. 170-181.

15. DAHAB, M., \& LEE, Y., Nitrate Removal from Water Supplies Using Biological Denitrification. Journal Water Pollution Control Federation, Vol.60, Nr.9, WPCF Annual Conference Issue (1988, September 1, p.1670-1674).

16. DU, R., PENG, Y., CAO, S., WU, C., WENG, D., WANG, S., HE, I., Advavanced nitrogen removal with simultaneaus Anammox and denitrification in sequencing batch reactor. Bioresurce Tehnology. 2014, 316-322.

17. FOGLAR, L., BRISKI, F., SIPOS, L., VUKOVIC., Highnitrate removal from synthetic wastewater with the mixed bacterial culture. Bioresurce Tehnology. 2005, 96, 879-888. 
18. IMHOFF, K., R., BODE, H., EVERS, P., Epurarea apelor reziduale. Statii comunale de epurare. Editura Tehnica Bucuresti, 1998.

19. MOARE, S.F., SCHRODER, E.D., The effect of nitrate feed rate on dennitrification. Water Resource. 1971, 5, p.445-452.

20. ROSSI, F., MOTTA, O., MATRELLA, S., PROTO, A., \& VIGLIOTTA, G., Nitrate Removal from Wastewater through Biological Denitrification with OGA 24 in a Batch Reactor. Jurnals/Water, Vol.7, Issue 1, 2014, Dec. 23.

21. *** EPA Anaerobic digestor mixing systems. JWPCF, 59, 3, 1987.

22. PARVU, C., Ecologie generala. Editura Tehnica Bucuresti, 2001, p. 238-560.

23. ZARNEA, C. Tratat de microbiologie generala. Editura Academiei Romane, vol. V, 1994.

24. SIDDIQUE, S., \& VARDO-ZALIK, A., (n.d.). The Effects of Available Glucose Concentration on the Population Dynamics of Growing Escherichia coli Cultures.

25. *** Evolutia $\mathrm{CBO}_{5}$ la Statia de Epurare a Municipiului Bistrita, Romania (2015).

26. $* * *$ HG 352/2005 privind conditiile de evacuare in mediul acvatic a apelor uzate.

Manuscript received: 16.03 .2020 